\title{
IDENTIFYING MECHANISMS TO DEVELOP INFORMATION TECHNOLOGY CAPABILITIES
}

\begin{abstract}
Information Technology capabilities are organizational skills which enable the IT function deliver value to the various activities of the company. This paper aims to analyze how some important IT capabilities such as internal relationship and technical skills were built during the design, implementation and dissemination of an integrated management system in a Brazilian public University, between the years 2004 and 2009. It was developed a cognitive map based on SODA methodology, identifying those feedback loops relevant in this context. It was possible to understand the whole process through a map categorization, which showed: how the integrated systems were designed based on the top management vision; the process of scope stretching which led to the development of new modules based on users participation; its widespread adoption based on the institution credibility; the learning mechanis ms performed by IT; and the organizational adjustments in the IT group which were necessary to maintain the development of technical capabilities and internal relationship. Based on interviews with actors involved, it was possible to identify these relevant mechanisms responsible for the lifecycle of IT capabilities: creation, development and stability. The analys is of this successful case can shed some light over the process of capabilities creation process.
\end{abstract}

Keywords: Organizational Capacity; Capacity Life Cycle; Information Technology Capabilities.

\section{IDENTIFICANDO MECANISMOS PARA DESENVOLVER CAPACIDADES DE TECNOLOGIA DA INFORMAÇÃO}

\section{RESUMO}

Capacidades de Tecnologia da Informação são habilidades organizacionais que possibilitam à função de TI entregar valor às diversas atividades da empresa. Este artigo tem como objetivo analisar como capacidades de TI relevantes , tais como capacidade de relacionamento interno e capacidade técnica, foram construídas durante a elaboração, implementação e disseminação do sistema integrado de gestão em uma instituição pública de ensino superior brasileira entre os anos de 2004 e 2009. Para tanto, foi desenvolvido um mapa cognitivo baseado na metodologia SODA, que possibilitou identificar os loops de feedback relevantes neste contexto. Assim, foi possível compreender este processo através das seguintes categorias advindas do mapa: a definição dos sistemas integrados a partir da visão da alta administração; o processo de estender o escopo resultante do desenvolvimento de novos módulos a partir da na participação dos usuários; a expansão da adoção dos sistemas combase na credibilidade da instituição; os mecanismos de aprendizado realizados no setor de TI; e os ajustes organizacionais no setor de TI necessários para manter o desenvolvimento das capacidades técnica e de relacionamento interno. Com base nas entrevistas com os atores envolvidos, foi possível identificar estes mecanismos relevantes responsáveis pelo ciclo de vida das capacidades de TI: criação, desenvolvimento e estabilidade. A análise deste caso bem-sucedido pode lançar uma luz sobre o processo de criação de capacidades.

Palavras-chaves: Capacidade Organizacional; Ciclo de Vida da Capacidade; Capacidades de Tecnologia da Informação. 


\section{IDENTIFICACIÓN DE MECANIS MOS PARA DESARROLLAR CAPACIDADES DE TECNOLOGÍA DE LA INFORMACIÓN}

\section{RESUMEN}

Las capacidades de tecnología de la información son habilidades organizativas que permiten a la función de TI entregar valor a las diversas actividades de la empresa. Este artículo tiene como objetivo analizar cómo las capacidades de TI relevantes, tales como capacidad de relación interna y capacidad técnica, fueron construidas durante la elaboración, implementación y diseminación del sistema integrado de gestión en una institución pública de enseñanza superior brasileña entre los años 2004 y 2009. Para tanto, se desarrolló un mapa cognitivo basado en la metodología SODA, que posibilitó identificar los bucles de feedback relevantes en este contexto. Así, fue posible comprender este proceso a través de las siguientes categorías provenientes del mapa: la definición de los sistemas integrados a partir de la visión de la alta administración; el proceso de extender el alcance resultante del desarrollo de nuevos módulos a partir de la participación de los usuarios; la expansión de la adopción de los sistemas en base a la credibilidad de la institución; los mecanismos de aprendizaje realizados en el sector de TI; y los ajustes organizativos en el sector de TI necesarios para mantener el desarrollo de las capacidades técnicas y de relaciones internas. Con base en las entrevistas con los actores involucrados, fue posible identificar estos mecanismos relevantes responsables por el ciclo de vida de las capacidades de TI: creación, desarrollo y estabilidad. El análisis de este caso exitoso puede arrojar luz sobre el proceso de creación de capacidades.

Palabras clave: Capacidad Organizativa; Ciclo de vida de la capacidad; Capacidades de Tecnología de la Información.

\footnotetext{
1 Doutorando em Administração pela Universidade Federal do Rio Grande do Norte - UFRN. Professor do curso de Sistemas de Informação na Universidade Federal do Rio Grande do Norte - UFRN. Brasil. E-mail: josuevitor16@gmail.com

${ }^{2}$ Doutor em Administração pela Universidade de São Paulo - USP. Professor da Universidade Federal do Rio Grande do Norte - UFRN. Brasil. E-mail: manoel.veras@uol.com.br

${ }^{3}$ Doutor em Administração de Empresas pela Escola de Administração de Empresas de São Paulo da Fundação Getulio Vargas - EAESP/FGV. Professor da Universidade Federal do Rio Grande do Norte - UFRN. Brasil. E-mail: anez1957@yahoo.com.br

${ }^{4}$ Doutor em Administração de Empresas pela Escola de Administração de Empresas de São Paulo da Fundação Getulio Vargas - EAESP/FGV. Professor da Fundação Educacional Inaciana Padre Sabóia de Medeiros - FEI. Brasil. E-mail: edmilson@fei.edu.br
} 


\section{INTRODUCTION}

Several studies aim to understand how the resources of Information Technology (IT) generate value for organizations (Bharadwaj, 2000; Wade and Hulland, 2004) . However, most of these resources are seen as commodities readily available on the market so that they are not considered strategic (Carr, 2003; Mata, Fuerst, and Barney, 1995). On the other hand, IT skills have been identified as responsible for superior operational and financial performance of organizations (Bharadwaj, 2000; Liang, You, and Liu, 2010; Stoel and Muhanna, 2009).

These organizational capabilities are characterized as the know-how that enables organizations to perform the relevant activities to their survival and competitiveness (Dosi, Nelson, and Winter, 2000). Actually, IT capabilities such as internal relationships and technical capacity (Barney and Clark, 2007; Ross, Beath, and Goodhue, 1996) allow IT effectively deliver services using resources that are complementary (Bharadwaj, 2000; Ravichandran and Lertwongsatien, 2005).

Despite the importance of organizational capabilities in general and in particular those of IT, few studies explore its formation over time (Ouyang, 2010; Pandža et al., 2003; Pregelj, 2013; Priem and Butler, 2001; Zhai, Shi, and Gregory, 2007). Those who deal with it, usually adopt the perspective of life cycle (Van de Ven, 1992) to explain how such organizational skills are created, developed, become mature and are discontinued (Helfat and Peteraf, 2003; Pregelj, 2013).

From this point of view, the context and characteristics related to each life cycle phase are identified, without an explanation of how underlying factors relate each other to better understand the resulting behavior of the organizational structure. Thus, identifying the "dominant logic" of the organizational policies that led to the construction of IT capabilities can support the development of new capabilities in other organizations facing challenges whose similar capabilities are required.

Such conceptual support was adopted on a single case study about the trajectory of IT capabilities during the design, implementation and dissemination of an integrated management system originated in a Brazilian University since 2004, which in 2015 was under an implementation in more than 30 institutions of the federal government in Brazil. Such integrated systems involve a system to support the academic activities of teaching, research and extension; another for administrative activities of finance, assets and contracts; and a third supporting human resources operations.

More specifically, this article aims to investigate how IT capabilities: internal relationship and technical were built during the design, implementation and dissemination of an integrated management system in a Brazilian public university, between the years 2004 and 2009 through the life cycle stages of the IT Capability: Creation, Development and Stability.

\section{IT CAPABILITIES}

Broadly speaking, if an organization has some capability, this means that this organization is able to perform activities through the mobilization of resources (Amit and Schoemaker, 1993; Grant, 2010). Capabilities can still be characterized as the know-how that enables organizations to perform activities such as the development of new products (Dosi et al., 2000). Thus a superior performance in a given activity implies the existence of specific capabilities (Amit and Schoemaker, 1993).

Moreover, the ability to perform activities in a satisfactory and reliable way implies in the existence of some capability (Helfat and Winter, 2011). This reliability is reflected in the performance pattern shown by routine activities (Winter, 2003). A capability is considered satisfactory if its resulting activities reach the desired standards, despite the opportunities for improving performance (Helfat and Peteraf, 2003). Thus, a series of activities can be considered as arising from a capability when their performance is satisfactory in several different situations (Schreyögg and Kliesch-Eberl, 2007).

The existence of a capability can be recognized in some patterns of behavior that characterize them, once to maintain a certain capability it is necessary to continuously perform its activities. Thus, the routines can be considered capabilities building blocks (Collis, 1994; Dosi et al., 2000; Helfat and Peteraf, 2003; Winter, 2000), being responsible for its embodiment (Nelson and Winter, 1982). Under this point of view, organizational routines are patterns of regular and predictable behavior with a persistent characteristic that determines organizational behavior and they can be inherited, mutate and selected. So, they can be defined as repeated and recognized standards of interdependent actions taken by multiple actors (Feldman and Pentland, 2003).

Capabilities are built internally in organizations (Schreyögg and Kliesch-Eberl, 2007; Teece, Pisano, and Shuen, 1997), unless when acquisitions or alliances occur (Helfat and Lieberman, 2002), and it takes time for it to present satisfactory results through the performance of its activities (Grant, 2010; Leonard-Barton, 1992; Winter, 2012). Their idiosyncratic characteristics make it difficult to be emulated (Cool, Dierickx, and Costa, 2012; Makadok, 2001).

The IT capability is recognized as the most appropriate factor to explain the contribution of IT resources on organizational performance, and it can be 
defined as the set of practices carried out by the organization to mobilize and develop IT resources in combination with other resources and capabilities (Bharadwaj, 2000; Liang et al., 2010; Stoel and Muhanna, 2009). The IT capability enables the IT function to provide services for the organization (Ravichandran and Lertwongsatien, 2005) and identify systems that meet organizational needs and develop them effectively (Ross et al., 1996).

IT capabilities can be classified as internal or external (Hulland, Wade, and Antia, 2007; Stoel and Muhanna, 2009). External capabilities are skills that help the organization to identify and adapt itself to cope with environmental changes, such as external relationship capability (Day, 1994; Ethiraj et al., 2005; Feeny and Willcocks, 1998; Wade and Hulland, 2004), capability to respond to environment (Rapp, Trainor, and Agnihotri, 2010; Wade and Hulland, 2004) and capability for planning and changing the IT (Bharadwaj, 2000; Ravichandran and Lertwongsatien, 2005; Wade and Hulland, 2004). On the other hand, internal capabilities help the organization to provide reliable products and services while minimizing unnecessary costs. Among others there are internal relationship capability (Bhatt and Grover, 2005; Feeny and Willcocks, 1998), technical capability (Barney and Clark, 2007; Hulland et al., 2007; Mata et al., 1995; Piccoli and Ives, 2005) and research and development capability (Wade and Hulland, 2004).

The internal relationship capability is the capability to promote a long lasting relationship between the experts in the organization's IT function and the users of technology, like managers of organizational units (Bharadwaj, Sambamurthy, and Zmud, 1999). It is based on the establishment of an ongoing and extensive dialogue between the IT function and the user community, leading to the emergence of trust and risk sharing behavior (Bhatt and Grover, 2005). The internal relationship capability is also important for the emergence of an understanding of the IT potential by users as well help them and IT specialists to work together and ensure the satisfaction and sense of ownership by both (Feeny and Willcocks, 1998).

By analyzing the effects of IT resources and capabilities on the performance of the insurance companies in the United States, Ray et al. (2005) found that the IT capability most valuable, rare and difficult to imitate, was the one based on the shared knowledge and common understanding between the IT group and customers relationship managers, and it proved to be critical to the performance of the customer services processes.

In another study, Bhatt e Grover (2005) classify internal relationship skills as competitive advantage sources, since they are valuable, are heterogeneously distributed across companies and are difficult to be transferred between different organizations. In addition, they follow a learning by doing dynamic making them very specific skill which were developed over the years.

The IT technical capability is related to the know-how required to design and develop effective information systems using the technology available and the know-how to use, implement and manage that knowledge to produce goods and services (Barney and Clark, 2007; Hulland et al., 2007; Piccoli and Ives, 2005). Thus it is associated with the knowledge about programming languages and database development environments, architectural standards for communication protocols and operating systems, for example.

Being the IT technical skills explicitly coded and due to the high mobility of skilled people from organizations, the IT technical capability is often not considered to be responsible for competitive advantage in organizations, since they do not obey the resource heterogeneity assumption (Barney and Clark, 2007; Mata et al., 1995).

On the other hand, some skills related to IT technical capabilities are difficult to be imitated, such as the mastering of knowledge assets at the corporate level, necessary for encoding the organizational business rules, and the technology integration skills, which are specific for each organization (Wade and Hulland, 2004).

\section{METHOD}

This qualitative research has identified the lifecycle of IT capabilities in a retrospective way (ETHIRAJ et al, 2005; Pandža et al, 2003). It is a case study selected for its importance in the regional context, since it originated in a state of the Brazilian northeast region not economically significant; and due to its rarity, as similar projects that started at the same time in different locations were not successful.

This research was divided into 3 phases. First the main historical events related to the development of the integrated system were identified and the process of design and diffusion occurred between the years 2004 and 2009 were analyzed.

Then, in a second phase, we identified the relevant IT capabilities existing in 2009 by its characteristics: organizational ability, achievement through routine, coordinated tasks, reliable performance and minimally satisfactory and specific outcome.

The 23 interviewees participating in these two phases, employees from the IT department and the organization's managers were selected for the role they played, and their participation in the historical process varied between three and eight years.

After that, in the last phase, we designed a qualitative model by adopting the methodology SODA (Strategic Options Development Analysis), in order to clarify the dynamics of the process. The adoption of 
SODA can be justified by the need to capture the causal logic in the relationship between the variables (Georgiou, 2011). This approach has already been adopted in other studies, when it was used to support system dynamics models (Howick, 2003; Lane and Olive, 1998). Following that, each SODA map was built on a single unified cognitive map.

This map was constructed from in-depth interviews with four members of the IT department in university who experienced the events between 2004 and 2009. Each map was merged in just one map and the constructs were clustered for better understanding.

Through the analysis domain SODA methodology proposed by the main map and constructs based on historical categorization been identified, the map was divided into five areas (categories) for better understanding. The resultant map of feedback loops were identified and related to the construction of IT capabilities. These loops have a central position in the analysis of the behavior of dynamic complex systems, given their great influence on these (STERMAN, 2000). The feedback loops were identified and related to each lifecycle stage of IT capabilities: creation, development and stability.

As a data triangulation strategy to increase the reliability of this research, secondary data sources were used from university normative documents, documentation repository and management system from University IT department. These data sources were important in confirming the information collected during the interviews.

For analysis and organization of the collected data, NVivo software version 10 was adopted. To support the arguments for each construct, parts of the interviews were selected and presented in the next topic.

\section{BUILDING IT CAPABILITIES}

The organization focus of this research is a public institution of higher education established in 1958 and considered the best university of the country's northeast region, which had approximately 36.000 students enrolled in its 68 academic departments in 2014. During the trajectory of development, availability and use of integrated systems, it was necessary to build capabilities to effectively deal with the growing challenges in the scope of the systems at the university and cooperation networks were established with other organizations.

The integrated management system analyzed in this research is mainly composed of three main systems: one to support the academic activities of teaching, research and extension; the other to support the administrative activities of finance, assets and contracts; and a third that perform human resources work processes. All of them are enhanced and maintained by the team members of the university's IT department.

Between 2004 and 2007, such system was in development and its first modules were made available to the academic and administrative sectors of the University. Later, between 2007 and 2009, the systems have been enhanced through new modules. During this period it was identified the need to build technical capabilities, by the development team, and the development of internal relationship capability by the development team and technical support staff.

In the context of this research, technical capability is the organizational ability to develop new features and bug fixes for users in the system in time and expected quality. When dealing with users of the systems at the university, the IT department has built an capability able to interact with them in a specific way (Ethiraj et al, 2005; Ross et al, 1996), characterizing the capability of internal relationship. It is defined as the organizational ability to support the effective use of systems by other units when meeting demands for improvements, bug fixes and doubts regarding the time and expected quality.

Figure 1 below displays the structure responsible for the development of these two capabilities in a merged cognitive map, presenting in its top the construct that is system development goal: Systems support to the activities of the University. 
Identifying Mechanisms to Develop Information Technology Capabilities

Figure 1 - The dynamic for the construction of technical and internal relationship capabilities

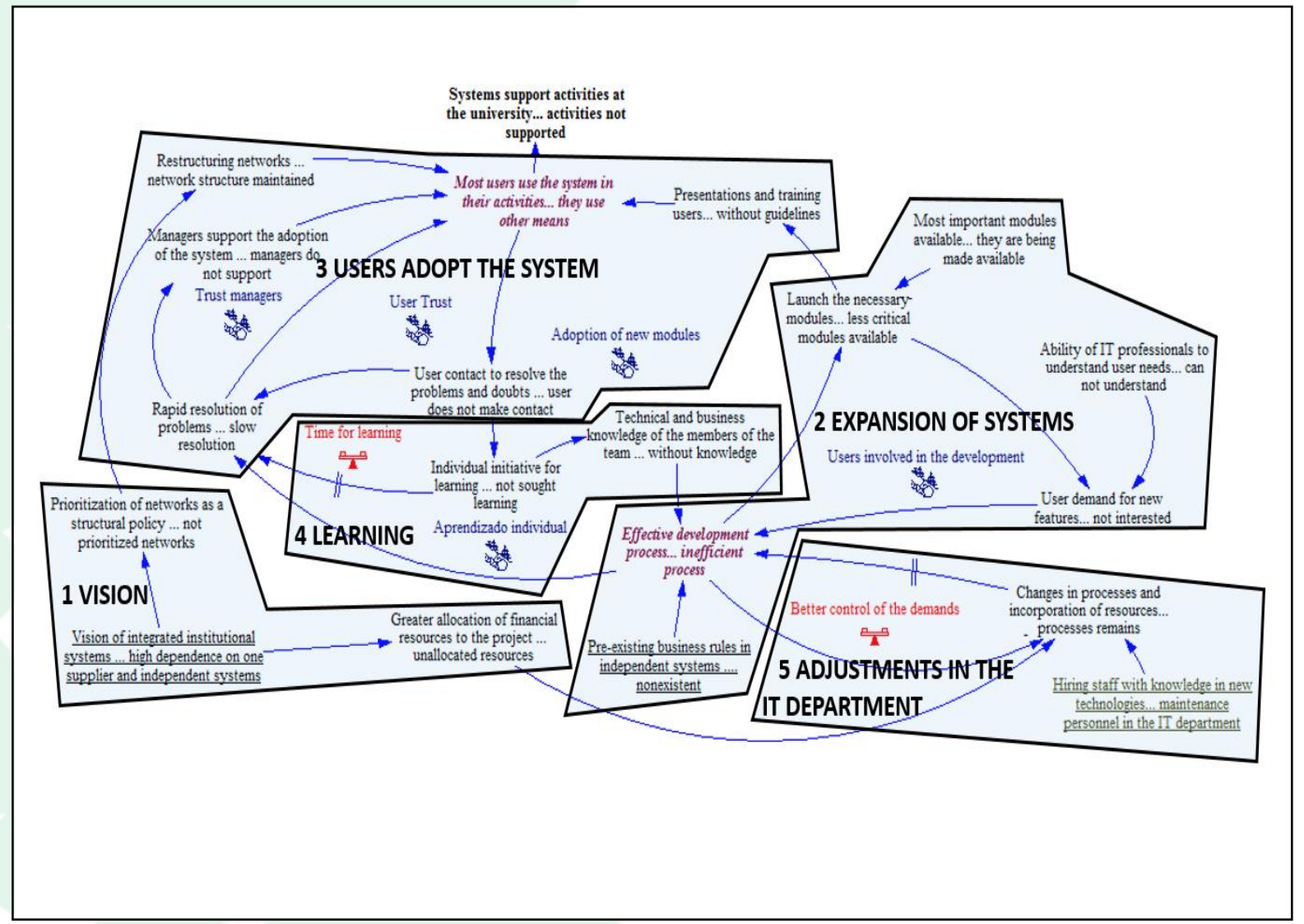

Overall, we identified two relevant constructs for achieving this goal, through SODA domain analysis method (Ackermann and Eden, 2010).

One is related to the objective on the map, since to achieve the objective of system supporting effectively most of the University activities, it was necessary that its use was spread in users daily activities (6 relations).

Another relevant construct is the effective development process (7 relations), involving the workflow from the arrival of a new demand (for development of a new module or request for error correction or clarification of doubts) until this demand is met. This process basically involved the IT department responsible for both service users and systems development, involving routines belonging to the two IT capabilities analyzed in this work.

There were also identified six feedback loops responsible for the dynamic behavior inherent to the process, four of reinforcement and two of balance. The map was further divided into five areas for better understanding: view definition (1), systems scope of expansion (2), the largest user adoption (3), the need to search for learning by members of the IT industry (4) and organizational adjustments in the IT department (5). Each area is presented in Figure 1. 


\subsection{Vision Definition (area 1)}

Figure 2 - Vision Definition

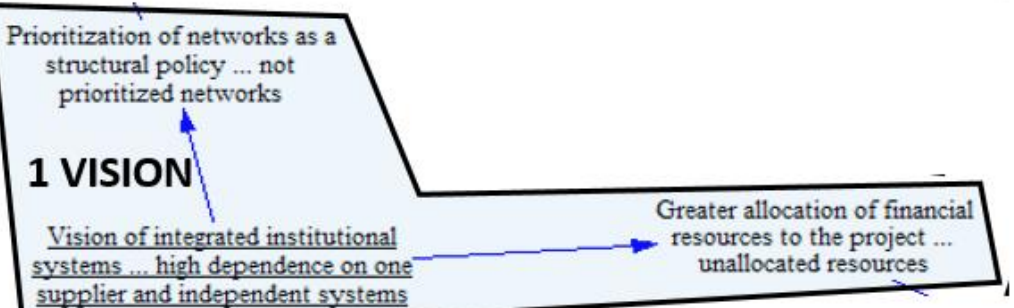

supplier and independent systems unallocated resources

Two main aspects defined the senior management vision to support the development of the system. First was the feeling of heavy dependence on an external supplier, which made it difficult to make changes and improvements to the system (1999-2000). Another aspect was the large number of independent systems that the University had at that time, making it difficult to generate reliable management reports (until 2006).

These aspects have led senior management to support the development of its own integrated system, to be developed by the organization's IT department, which implied in a huge allocation of financial resources to acquire more infrastructure and to hire more people for the IT department, initially through a team. According to the managers at the time:

[...] it was a consensus among us that the university should no longer be held hostage by any external supplier ... the university had no integrated system at all ... everything was outsourced or isolated, is lands of systems. [...] (verbal information)

[At first] the idea was just to solve a problem [of Sector X], which had a system there and they complained a lot ... we set up the group there with the support of the managers [...] and then came the demand of the building just as being made for the administrative area also came the demand to make to the academic area as a integrated systems. (verbal information)

They also tried to raise funds from the federal government to investment in the expansion of their networks so systems would have greater availability. These senior management initiatives took place throughout the period in which the systems were being developed and were essential to their success (20022007).

Thus, it is possible to consider the view of the university managers and resulting actions as responsible for the creation phase of the technical and internal relationship capability, given the need to have access and assimilation of knowledge (Ouyang, 2010) to build the integrated system and the existence of a narrow group of individuals organized around a goal in terms of problems or challenges with greater prominence of Individual skills (Helfat and Peteraf, 2003).

Besides that, the performance of activities related to these capacities was non-existent (Pregelj, 2013) and the resources incorporated into these activities were primarily the result of individual efforts (Zhai et al., 2007). 
Figure 3-System Scope Expansion

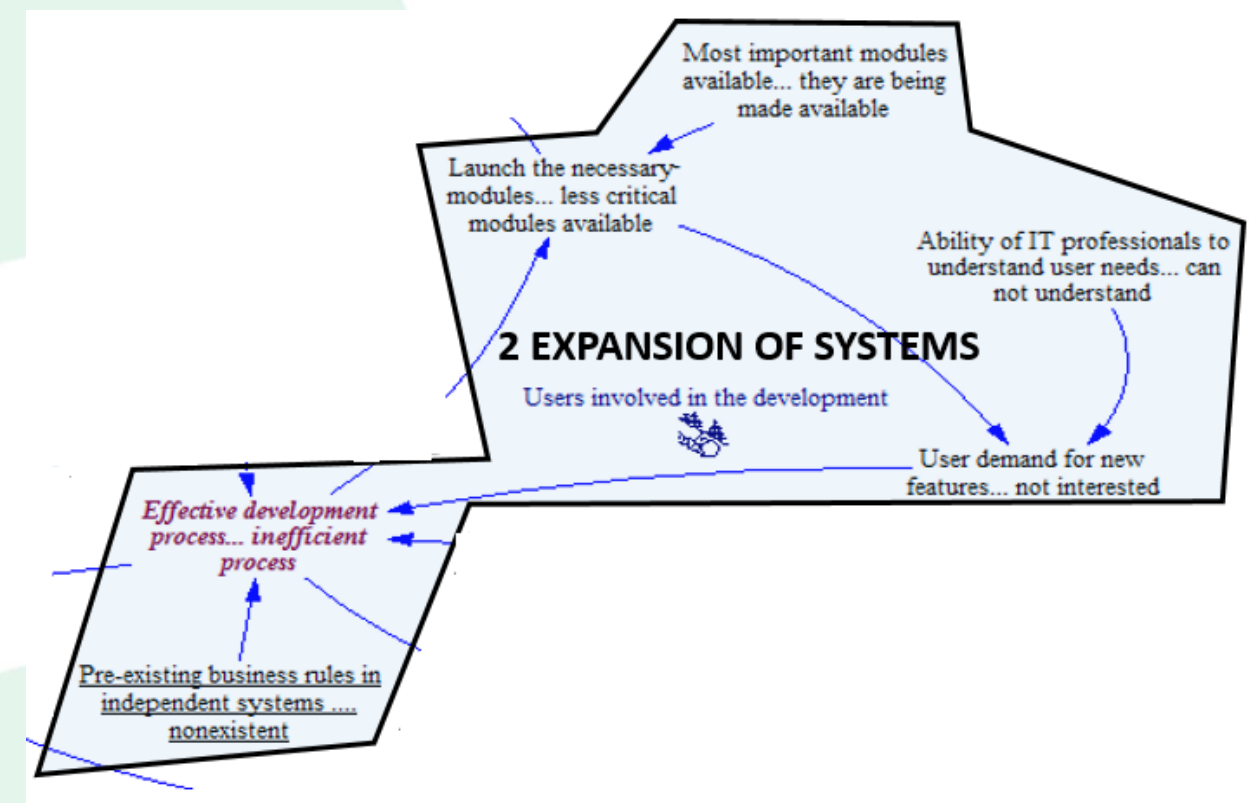

To be adopted at the university as a whole, it was necessary that the development of the system new modules got involved the users from several areas of the organization who had good knowledge about the work processes in their area.

This is explained by the reinforcing loop Users Participate in Development. In that context, the IT department launched new modules based on requirements pooled with users so that other users became aware of their advantages, and it triggered more requests for new modules in other areas.

This loop is responsible for the improvement of the system scope, and its strength reinforced by focus of the IT department in investing in the developing of the main modules, those ones which would be used more intensively, as one of the interviewees explains:
Our strategy was always the core business [...] it's that people like to work in the exception and you have to know how to filter it [...] So they often wanted to go in the coolest operation to build. We always tried to do the core to then go growing... but the question is, "which one is most important to him?" "Which one does he use daily?" this is the core business ... then you would implant [the feature] and the user would ask for more. (verbal information)

This dynamics was relevant during the development and stability phases of technical capability, since the interactions with the users resulted in improvements to the development activities (Helfat and Peteraf, 2003) and this capability was constantly exercised through development of new features at a later period. 


\subsection{Systems Adoption (area 3)}

Figure 4 - System Adoption

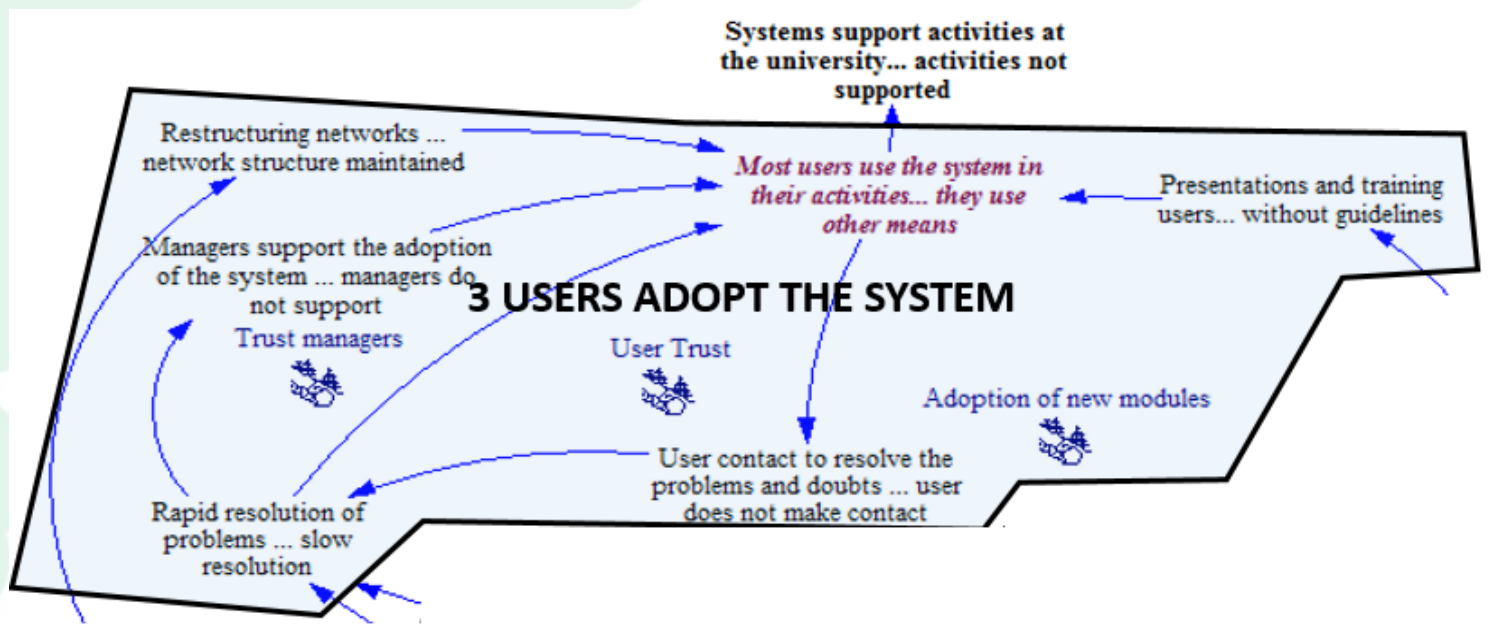

From 2006, after launching new modules, the University began to establish a training policy for the main users groups. The goal was that employees could incorporate the use of the system in their daily activities. At that time, senior management had achieved major expansion of the University computer networks, increasing the performance and availability of the deployed systems. These factors, enhanced the relationship among the early users and the IT staff to solve problems they faced.

As the IT department quickly responded to such demands for problem solving, it led to an increase credibility (trust) from the users and the University managers, as evidenced by an interviewee:

There is always the problem that if the manager trusts but IT does not deliver, he can not sustain for long. We always worked to make users believe [...] and we worked hard at that time to solve the problems, and each deployment was a difficult scenario [...] as we responded quickly, the system evolved and users and managers passed to trust more. (verbal information)

Thus, system adoption dynamics was responsible for the development and stability of the internal relationship capacity between the IT unit and the other units of the university. As for the last phase of the life cycle, between 2008 and 2009, training had become an institutional policy and users already knew how their demands could be met by the IT department. Thus, the routines stabilized and the capacity for internal relationships had already become entrenched in the organization (Ouyang, 2010).

\subsection{Demand for Learning (area 4)}

Figure 5 - Demand for Learning

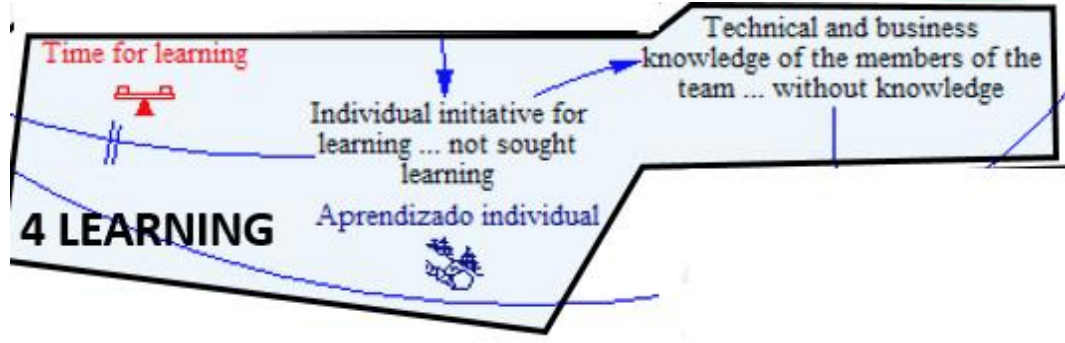


To keep the agility and quick response to the problems posed by users, the IT staff had to study and research about the many problems presented. This process contributed to the development of their technical and business expertise (related to business rules), improving development process. This dynamic is captured by the individual learning reinforcement loop.

This loop was responsible for the accumulation of process knowledge (about the business processes supported by the system worked), and of technical knowledge (about architecture, code sys tems and database structure are implemented). This learning was responsible for reducing the response time to users requests.

The knowledge search was performed by individual motivation, once there was no specific enforcement from the IT managers. It is noteworthy that this accumulation of knowledge proved to be the fuel for development of technical capabilities and internal relationship capability. This fact was reinforced by one of the technical managers, regarding the period in which the technical capacity was in development:

It was a period of much learning and development, I began to study new things, which I did not know and that most of the team did not know, so it was a process of growth, personal and technical, both mine and the team. [...] we organized a group of Java [Programming Language] users, we started to do small workshops, small lectures, but also big events. (verbal information)

These learning initiatives favored the development of both capabilities as they resulted in local searches characterized by experimentation, making internal technical and relationship routines better (Zhai et al., 2007; Pandza et al., 2003).

\subsection{Organizational Adjustments in IT Department (area 5)}

Figure 5 - Organizational Adjustments in IT department

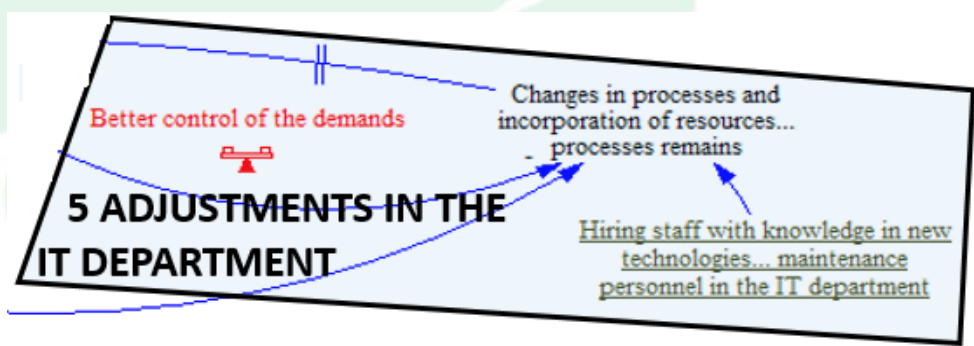

When the demands for new features and bug fixes or clarification of doubts were too busy, decreasing the effectiveness of the development, the IT managers invested on the acquisition of new resources (technological, human, physical, organizational) and in the restructuring of the development process itself, generating changes that led to the return of the effectiveness of the development process.

This dynamic of organizational adjustments in the IT department is accounted for initiatives such as the creation of new teams in the IT area, new positions, creation of new steps in the implementation process, such as approval and quality testing, for example, and incorporation of new technological tools, such as the creation of a whole process control system. Regarding the changes in the IT unit organizational structure, one of the interviewees explains:
Then there was the unification of the development sectors and the system board was created to coordinate each sector, there was also created a support team to serve the others units users [...] All this because of the [many] demands [of users] and the size and the importance that the systems have had in the university. (verbal information)

Similar to the dynamics presented in the previous section, these adjustments proved to be necessary to the development of technical capabilities and internal relationship, characterized by intense trials on how to improve the process of development and changes in routines and processes, activities that characterize the development of capabilities (George, 2005; Pregelj, 2013).

The following table 1 exhibit the role of the categories identified in the creation and development of technical capabilities and internal relationship: 
Identifying Mechanisms to Develop Information Technology Capabilities

Table 1 - Identified Categories and their Role in Building Capabilities

\begin{tabular}{|c|c|c|}
\hline CATEGORY & ROLE IN CAPABILITIES BUILDING & LIFE CYCLE CAPABILITY \\
\hline Vision Definition & $\begin{array}{l}\text { Definition of the right context for the creation } \\
\text { of technical and internal relationship } \\
\text { capabilities when financial resources were } \\
\text { allocated for the acquisition and expansion of } \\
\text { IT infrastructure assets (networks, for } \\
\text { example) and hiring IT professionals }\end{array}$ & $\begin{array}{c}\text { Technical Capability and Internal } \\
\text { Relationship Creation }\end{array}$ \\
\hline $\begin{array}{l}\text { System Scope } \\
\text { Expansion }\end{array}$ & $\begin{array}{l}\text { Intense exercise of technical capability } \\
\text { activities for the implementation of new } \\
\text { features in the systemand internal relationship } \\
\text { capability activities through interaction with } \\
\text { specific user groups for requirements } \\
\text { specification }\end{array}$ & $\begin{array}{c}\text { Technical Capability Development } \\
\text { and Stability }\end{array}$ \\
\hline Systems Adoption & $\begin{array}{l}\text { Intense exercise of the internal relationship } \\
\text { capability activities through interactions with a } \\
\text { larger universe of users (clarification of } \\
\text { doubts, for example) }\end{array}$ & $\begin{array}{l}\text { Internal Relationship Capability } \\
\text { Development and Stability }\end{array}$ \\
\hline $\begin{array}{l}\text { Demand for } \\
\text { Learning }\end{array}$ & $\begin{array}{l}\text { Incorporation of new technical and business } \\
\text { knowledge, important resources used in the } \\
\text { improvement of the activities of the technical } \\
\text { and internal relationship capabilities }\end{array}$ & $\begin{array}{l}\text { Technical Capability and Internal } \\
\text { Relationship Development }\end{array}$ \\
\hline $\begin{array}{l}\text { Organizational } \\
\text { Adjustments in IT } \\
\text { Department }\end{array}$ & $\begin{array}{l}\text { Development and changes in human, } \\
\text { technological, organizational and physical } \\
\text { resources, used in the improvement of the } \\
\text { technical and internal relationship capabilities }\end{array}$ & $\begin{array}{c}\text { Technical Capability and Internal } \\
\text { Relationship Development }\end{array}$ \\
\hline
\end{tabular}

\section{CONCLUSION}

This article aims to show how the internal relationship and technical capabilities of IT were built during the design, implementation and dissemination of an integrated management system in a Brazilian public University, between the years 2004 and 2009. It was thus drawn up a cognitive map based on SODA methodology, which was relevant to capture the understanding of the respondents of the dynamics involved in this phenomenon.

In general, the organization view of the top management has been identified as an important factor for creating both capabilities. With regard to lifecycle development phase, it was possible to identify that the execution of the routines (represented by the expansion in the scope and adoption of the system by the users) demanded learning and organizational adjustments in the IT department. Finally, the stability of capabilities was characterized by the stable exercise of technical and relationship routines.

The results of this work leads to a theoretical contribution due to the absence in the literature of underlying process responsible for the lifecycle of capabilities. Currently, in the strategy area, much of the research focused on dynamic capabilities, for example, is based on studies that ignore procedural aspects on the creation and development of capabilities.
As a managerial contribution, considering that this was a successful case, being currently implemented in other Brazilian organizations since 2009 , it is possible to identify the best practices in the construction of relevant IT capabilities which permitted the systems to support much of its activities in those organizations that are currently implementing the same integrated systems in cooperation with the university.

As work limitation, the data collected were based on past events and not while they occurred. Moreover, it was not possible to interview all key stakeholders in the process nor to extend the analysis to a larger historical period.

The next step in this research is to develop a simulation model using System Dynamics, to get insights about the dynamics of capabilities creation and about the dynamics of technology diffusion. 


\section{REFERENCES}

Ackermann F, C Eden. 2010. Strategic options development and analysis, Systems approaches to managing change: A practical guide. Springer, pp. 135-190.

Amit R, PJ Schoemaker. 1993. Strategic assets and organizational rent. Strategic management journal 14(1): 33-46.

Barney JB, DN Clark. 2007. Resource-based theory: Creating and sustaining competitive advantage. Oxford University Press Oxford, Oxford.

Bharadwaj A. 2000. A resource-based perspective on information technology capability and firm performance: an empirical investigation. MIS Quarterly: 169-196.

Bharadwaj A, V Sambamurthy, RW Zmud. 1999. IT capabilities: theoretical perspectives and empirical operationalization. Proceedings of the Proceedings of the 20th international conference on Information Systems, pp. 378-385. Association for Information Systems.

Bhatt GD, V Grover. 2005. Types of information technology capabilities and their role in competitive advantage: an empirical study. Journal of management information systems 22(2): 253-277.

Carr NG. 2003. TI já não importa. Harvard business review 81(5): 30-37.

Collis DJ. 1994. Research note: how valuable are organizational capabilities? Strategic management journal 15(S1): 143-152.

Cool K, I Dierickx, L Costa. 2012. Economies of Resource Accumulation.

Day GS. 1994. The capabilities of market-driven organizations. the Journal of Marketing: 37-52.

Dosi G, R Nelson, S Winter. 2000. The nature and dynamics of organizational capabilities. Oxford University Press.

Ethiraj SK, P Kale, MS Krishnan, JV Singh. 2005. Where do capabilities come from and how do they matter? A study in the software services industry. Strategic management journal 26(1): 25-45.

Feeny DF, LP Willcocks. 1998. Core IS capabilities for exploiting information technology. Sloan management review 39(3): 9-21.
Feldman MS, BT Pentland. 2003. Reconceptualizing organizational routines as a source of flexibility and change. Administrative science quarterly 48(1): 94118.

George G. 2005. Learning to be capable: patenting and licensing at the Wisconsin Alumni Research Foundation 1925-2002. Industrial and corporate change 14(1): 119-151.

Georgiou I. 2011. Cognitive mapping and strategic options development and analysis (SODA). Wiley Encyclopedia of Operations Research and Management Science.

Grant RM. 2010. Contemporary strategy analysis and cases: text and cases. Wiley.

Helfat CE, MB Lieberman. 2002. The birth of capabilities: market entry and the importance of pre-history. Industrial and corporate change 11(4): 725-760.

Helfat CE, MA Peteraf. 2003. The dynamic resource-based view: capability lifecycles. Strategic management journal 24(10): 997-1010.

Helfat CE, SG Winter. 2011. Untangling Dynamic and Operational Capabilities: Strategy for the (N) ever-Changing World. Strategic management journal 32(11): 1243-1250.

Howick S. 2003. Using system dynamics to analyse disruption and delay in complex projects for litigation: can the modelling purposes be met? Journal of the Operational Research Society 54(3): 222-229.

Hulland J, MR Wade, KD Antia. 2007. The impact of capabilities and prior investments on online channel commitment and performance. Journal of management information systems 23(4): 109-142.

Lane DC, R Oliva. 1998. The greater whole: Towards a synthesis of system dynamics and soft systems methodology. European Journal of Operational Research 107(1): 214-235.

Leonard-Barton D. 1992. Core capabilities and core rigidities: A paradox in managing new product development. Strategic management journal 13(S1): 111-125.

Liang T-P, J-J You, C-C Liu. 2010. A resource-based perspective on information technology and firm performance: a meta analysis. Industrial Management \& Data Systems 110(8): 1138-1158. 
Makadok R. 2001. Toward a synthesis of the resource-based and dynamic-capability views of rent creation. Strategic management journal 22(5): $387-401$.

Mata FJ, WL Fuerst, JB Barney. 1995. Information technology and sustained competitive advantage: a resource-based analysis. MIS Quarterly: 487-505.

Nelson RR, S Winter. 1982. An evolutionary theory of economic change. Harvard University Press.

Ouyang H. 2010. Imitator-to-innovator S curve and chasms. Thunderbird International Business Review 52(1): 31-44.

Pandža K, A Polajnar, B Buchmeister, R Thorpe. 2003. Evolutionary perspectives on the capability accumulation process. International Journal of Operations \& Production Management 23(8): 822849.

Piccoli G, B Ives. 2005. Review: IT-dependent strategic initiatives and sustained competitive advantage: a review and synthesis of the literature. MIS Quarterly 29(4): 747-776.

Pregelj L. 2013. Capability development along the capability lifecycle: Evidence from the pharmaceutical industry, UQ Business School, The University of Queensland Austrália.

Priem RL, JE Butler. 2001. Is the resource-based "view" a useful perspective for strategic management research? Academy of management Review 26(1): 22-40.

Rapp A, KJ Trainor, R Agnihotri. 2010. Performance implications of customer-linking capabilities: Examining the complementary role of customer orientation and CRM technology. Journal of Business research 63(11): 1229-1236.

Ravichandran T, C Lertwongsatien. 2005. Effect of information systems resources and capabilities on firm performance: a resource-based perspective.
Journal of management information systems 21(4): 237-276.

Ross JW, CM Beath, DL Goodhue. 1996. Develop long-term competitiveness through IT assets. Sloan management review 38(1): 31-42.

Schreyögg G, M Kliesch-Eberl. 2007. How dynamic can organizational capabilities be? Towards a dual-process model of capability dynamization. Strategic management journal 28(9): 913-933.

Stoel DM, WA Muhanna. 2009. IT capabilities and firm performance: A contingency analysis of the role of industry and IT capability type. Information \& Management 46(3): 181-189.

Teece DJ, G Pisano, A Shuen. 1997. Dynamic capabilities and strategic management. Strategic management journal 18(7): 509-533.

Van de Ven AH. 1992. Suggestions for studying strategy process: a research note. Strategic management journal 13(5): 169-188.

Wade M, J Hulland. 2004. Review: The resource-based view and information systems research: Review, extension, and suggestions for future research. MIS Quarterly 28(1): 107-142.

Winter SG. 2000. The satisficing principle in capability learning. Strategic management journal 21(10-11): 981-996.

Winter SG. 2003. Understanding dynamic capabilities. Strategic management journal 24(10): 991-995.

Winter SG. 2012. Capabilities: their origins and ancestry. Journal of management studies 49(8): 1402-1406.

Zhai E, Y Shi, M Gregory. 2007. The growth and capability development of electronics manufacturing service (EMS) companies. International Journal of Production Economics 107(1): 1-19. 